[Agr. Biol. Chem., Vol. 32, No. 9, p. 1175 1180, 1968]

\title{
Utilization of Alcohols by Hansenula miso
}

\author{
By Tokuya Harada and Takashi Hirabayashi \\ Institute of Scientific and Industrial Research, Osaka University, \\ Suita-shi, Osaka, Japan \\ Received April 18, 1968
}

\begin{abstract}
The ability of Hansenula miso IFO 0146 to utilize various alcohols and acidic salts as sole sources of carbon and the ability of resting cells to oxidize various alcohols and glucose were studied. Growing cells could utilize only ethanol, glycerol, acetate and lactate, while resting cells grown on ethanol medium could oxidize various alcohols such as 1,2-ethanediol, DL-1,2-propanediol, 1,3-propanediol, meso-2,3-butanediol, DL-1,3-butanediol, and 1,4-butanediol. From $2 \mathrm{~g}$ of 1,2-ethanediol and DL-1,3-butanediol, $1.3 \mathrm{~g}$ of glycolic acid and $0.5 \mathrm{~g}$ of $\beta$-hydroxybutyric acid respectively were produced. The organism formed D-arabinitol from glycerol and glucose, respectively. From $100 \mathrm{ml}$ of culture in medium containing $6 \mathrm{ml}$ of ethanol and $3.0 \mathrm{~g}$ of $\left(\mathrm{NH}_{4}\right)_{2} \mathrm{HPO}_{4}$ as carbon and nitrogen sources $3.40 \mathrm{~g}$ of dried cells were obtained.
\end{abstract}

Various acetic acid bacteria can oxidize a variety of compounds. Particularly interesting and extensive studies on their oxidation of aliphatic glycols have been made by Kersters $e t$ al. ${ }^{11}$ These oxidations gave a series of interesting end products, which could be obtained easily and in good yield. Oxidations of glycols by organisms other than Acetobacter and Gluconobacter have scarcely been studied. Alcaligenes faecalis var. myxogenes 10C3 was shown by us $^{2,31}$ to oxidize 1,2ethanediol to form a carbonic compound and succinoglucan. Corynebacterium E17 was also shown by $\mathrm{us}^{4 /}$ to oxidize ethanolamine to glycine. Oxidations of alcohols including glycols by yeast have not been studied extensively. This paper describes the utilization of alcohols particularly of glycols, and their oxidation products by Hansenula miso IFO 0146. Studies on the products from ethanol

1) K. Kersters and J. DeLey, Biochim. Biophys. Aata, 71, 311 (1963).

2) T. Harada and T. Yoshimura, J. Ferment. Technol., 42, 615 (1964).

3) T. Harada, Arch. Biochem. Biophys., 112, 65 (1965).

4) T. Harada and Y. Murooka, J. Ferment. Technol., 44, 192 (1966). by various strains of yeast will be published in near future.

\section{METHODS}

Organism. Of many strains of yeast used, Hansenula miso IFO 0146 was selected in our experiments. This organism has already been shown to be capable of utilizing ethanol as a sole source of carbon. ${ }^{5,6}$. The medium contained $150 \mathrm{mg}$ of $\left(\mathrm{NH}_{4}\right)_{2} \mathrm{HPO}_{4}, 100$ mg of $\mathrm{KH}_{2} \mathrm{PO}_{4}, 50 \mathrm{mg}$ of $\mathrm{MgSO}_{4} \cdot 7 \mathrm{H}_{2} \mathrm{O}, 1 \mathrm{mg}$ each of $\mathrm{NaCl}, \mathrm{MnCl}_{2} \cdot 4 \mathrm{H}_{2} \mathrm{O}$ and $\mathrm{FeCl}_{3} \cdot 6 \mathrm{H}_{2} \mathrm{O}$ in $100 \mathrm{ml}$ of distilled water and various compounds were added as carbon sources at the concentrations shown in the results. The medium was adjusted to $\mathrm{pH} 7.2$. Volatile alcohols were filtered through a Seitz filter and then added to the autoclaved medium.

Culture conditions. Volumes of $95 \mathrm{ml}$ of medium in $500 \mathrm{ml}$ conical flasks were inoculated with $5 \mathrm{ml}$ of seed culture which had been grown in the same medium. The culture was shaken reciprocally at 120 strokes with a distance of $7 \mathrm{~cm}$ per min at $30^{\circ} \mathrm{C}$ for three days unless otherwise stated.

Assay of growth. The organism was harvested by centrifugation at $6000 \mathrm{rpm}$ for $15 \mathrm{~min}$, washed twice with saline and dried to constant weight in

5) M. Mogi, Nippon Nogeikagaku Kaishi, 18, 733 (1942).

6) Y. Murooka and T. Harada, J, Bact., in press. 
vacuo over $\mathrm{P}_{2} \mathrm{O}_{5}$ at $90^{\circ} \mathrm{C}$.

oxidation by resting cells. Cells were harvested after three days growth on medium containing ethanol as a sole source of carbon and washed three times by suspending them in $0.02 \mathrm{M}$ phosphate buffer $(\mathrm{pH} 7.2)$ and centrifuging the suspension at $6000 \mathrm{rpm}$ for $15 \mathrm{~min}$. They were finally suspended in $0.02 \mathrm{M}$ phosphate buffer ( $\mathrm{pH}$ 7.2) at a concentration of about $20 \mathrm{mg}$ of living cells (wet weight) per $\mathrm{ml}$ and used at once for oxidation experiments. To each $2 \mathrm{ml}$ of cell suspensions was added $2 \mathrm{ml}$ of $1 \%$ solution of one of the various alcohols and the reaction mixtures were incubated aerobically at $30^{\circ} \mathrm{C}$ for $20 \mathrm{hr}$. The supernatant was obtained by centrifugation. The oxidation products were analyzed by paper chromatography using Toyo-roshi No. 52 paper with the developing solvent: $n$-butanol: acetic acid: water $=$ $4: 1: 5 \mathrm{v} / \mathrm{v}$ (solvent A). Bromocresol-green and ammoniacal silver nitrate reagents were used for detection of acidic and reducing matters, respectively. For chromatography 20 to $40 \mu \mathrm{l}$ samples were used routinely for spotting on paper.

Chemicals. All chemicals used were of the highest quality available commercially.

\section{RESULTS}

Growth on alcohols and acidic salts

Of the various alcoholic compounds tested, only ethanol and glycerol supported growth (Table I). Additional substrates that were tested and found not to support growth in-

TABLE I. UTILIZATION OF VARIOUS ALCOHOLS AS SOle SOURCES OF Carbon

Alcohol
$1 \%$
Methanol
Ethanol
$n$-Propanol
$n$-Butanol
1,2-Ethanediol
DL-1,2-Propanediol
1,3-Propanediol
DL-1,3-Butanediol
1,4-Butanediol
meso-2,3-Butanediol
Glycerol
DL-1,2,4-Butanetriol
Pentaerythritol
Glucose

Yield of cells
mg dry wt./100 ml
0
580
3
1
1
2
1
0
0
1
560
0
0
108

cluded methanol, $n$-propanol, $n$-butanol, 1,2ethanediol, DL-1,2-propanediol, 1,3-propanediol, DL-1,3-butanediol, 1,4-butanediol, meso2,3-butanediol, DL-1,2,4-butanetriol and pentaerythritol. Of the acidic compounds tested, only acetate and lactate supported growth (Table II). Compounds in the tricarboxylic acid cycle (succinate, malate, fumarate and citrate) and propionate, $n$-butyrate, glycollate, malonate and $\beta$-hydroxy-butyrate did not support growth. In these experiments, various substrates were tested at a final concentration

Table II. Utilization of Various Organic Acids as Sole Sources of Carbon

\begin{tabular}{lr} 
Acidic salt & \multicolumn{2}{c}{ Yield of } \\
Acetate & mg dry wt. \\
Propionate & 70 \\
$n$-Butyrate & 0 \\
Glycollate & 0 \\
Lactate & 2 \\
Malonate & 183 \\
Succinate & 0 \\
Malate & 2 \\
Fumarate & 1 \\
Citrate & 2 \\
$\beta$-Hydroxybutyrate & 2 \\
& 0
\end{tabular}

Table III. Production of Cells in Ethanol-, GLYCEROL- AND GLUCOSE-AMMONIUM MEDIA

$\begin{array}{cccc}\text { Carbon } & \begin{array}{c}\text { Amount } \\ \text { added } \\ \text { source }\end{array} & \begin{array}{c}\left.\mathrm{NH}_{4}\right)_{2} \mathrm{HPO}_{4} \\ \text { added } \\ \mathrm{gl} / 100 \mathrm{ml}\end{array} & \begin{array}{c}\text { Yield of cells. } \\ \text { g dry } \\ \text { wt. } / 100 \mathrm{ml}\end{array} \\ \text { Ethanol } & 2 & 0.3 & 0.67 \\ & 2 & 0.6 & 0.74 \\ & 2 & 1.0 & 1.01 \\ & 4 & 0.6 & 1.13 \\ & 4 & 1.2 & 1.90 \\ & 4 & 2.0 & 1.44 \\ & 6 & 0.9 & 1.53 \\ \text { Glycerol } & 6 & 1.8 & 2.87 \\ & 6 & 3.0 & 3.40 \\ & 2 & 1.0 & 0.47 \\ \text { Glucose } & 4 & 2.0 & 1.27 \\ & 6 & 3.0 & 2.00 \\ & 2 & 1.0 & 0.39 \\ & 4 & 2.0 & 0.99\end{array}$


of $1 \mathrm{~g}$ (or $1 \mathrm{ml}$ with liquid substrates) per $100 \mathrm{ml}$ of medium. Yields of $580 \mathrm{mg}$ and $560 \mathrm{mg}$ cells were obtained with ethanol and glycerol, respectively, while only $108 \mathrm{mg}$ cells were obtained with glucose. Much lower cell yields were obtained with acetate and lactate than with ethanol and glycerol.

The effects of the concentration of ethanol, glycerol and glucose on cell production were examined (Table III). $\left(\mathrm{NH}_{4}\right)_{2} \mathrm{HPO}_{4}$ was used as nitrogen source and the concentrations added were increased with increase in concentration of carbon compounds. The organism was cultured for six days. In the case of ethanol, $2 \%(\mathrm{v} / \mathrm{v})$ was added initially and the concentrations added were raised to $4 \%$ $(\mathrm{v} / \mathrm{v})$ with two flasks after $48 \mathrm{hr}$ incubation and to $6 \%(\mathrm{v} / \mathrm{v})$ with one flask after $72 \mathrm{hr}$ incubation. When $6 \%$ ethanol was added initially, growth was poor. High yields of $1.01 \mathrm{~g}, 1.90 \mathrm{~g}$ and $3.40 \mathrm{~g}$ of dried cells were obtained with $2 \%, 4 \%$ and $6 \%$ concentrations of ethanol in the presence of the optimal amount of the nitrogen compound. Among 2,4 and $6 \%$ glycerol concentration of the medium, a $6 \%$ concentration gave the highest yield $(2.00 \mathrm{~g} / 100 \mathrm{ml})$. The yield of cells from glucose was quite low. With $4 \%$ and $6 \%$ glucose two spots with $R f$ values of 0.44 and 0.58 in solvent $\mathrm{A}$, were detected with ammoniacal silver nitrate reagent. These com- pounds seemed to be sugar alcohols since they did not reduce Fehlings' solution or give colour reactions with $p$-anisidine reagent. These compounds were shown by paper chromatography to be erythritol and glycerol, respectively, by comparing their $R f$ values with those of authentic samples.

\section{Oxidation of alcohols}

The oxidation of various alcohols, particularly glycols by resting cells was studied. The incubation mixtures containing the acids formed, were centrifuged and the cations were removed from the supernatants with Dowex $50\left(\mathrm{H}^{+}\right)$. Then the products were identified by paper chromatography. The results with glycols are summarized in Table IV. The organism oxidized 1,2-ethanediol, 1,3-propanediol, 1,4-butanediol and DL-1,3butanediol, forming glycolic acid, $\beta$-hydroxypropionic acid, $\gamma$-hydroxybutyric acid and $\beta$-hydroxybutyric acid respectively. The products from DL-1,2-propanediol and meso-2,3butanediol gave spots of $R f \quad 0.77$ and 0.84 respectively on paperchromatogram using solvent $\mathrm{A}$, and these $R f$ values coincided with those of authentic samples of acetol and acetoin. Addition of $n$-propanol and $n$-butanol decreased the $\mathrm{pH}$ of the reaction mixture from 7.2 to $4.4 \sim 4.6$. This suggests that some acidic compounds were formed from them also, possibly propionic and $n$-butyric acids

Table IV. Paper Ghromatographic Analysis of Reaction Mixture after Oxidation of Various GLycols BY RestiNg CELLS

$\begin{array}{lccc} & \begin{array}{c}R f \text { in } n \text {-butanol: } \\ \text { acetic acid: water } \\ (4: 1: 5 \mathrm{v} / \mathrm{v})\end{array} & \begin{array}{c}R f \text { in } n \text {-butanol: } \\ \text { formic acid: water } \\ (19: 1: 10 \mathrm{v} / \mathrm{v})\end{array} & \begin{array}{c}R f \text { in phenol: } \\ \text { formic acid : water } \\ (75: 1: 25 \mathrm{v} / \mathrm{v})\end{array} \\ \begin{array}{l}\text { Oxidation product from 1,2-ethandiol } \\ \text { Authentic glycolic acid }\end{array} & 0.64 & 0.46 & 0.64 \\ \text { Oxidation product from 1,3-propanediol } & 0.64 & 0.46 & 0.64 \\ \text { Authentic } \beta \text {-hydroxypropionic acid } & 0.74 & 0.64 & 0.66 \\ \text { Authentic malonic acid } & 0.74 & 0.64 & 0.66 \\ \text { Oxidation product from 1,4-butanediol } & 0.62 & 0.28 & 0.47 \\ \text { Authentic } \gamma \text {-hydroxybutyric acid } & 0.82 & 0.80 & 0.83 \\ \text { Oxidation product from DL-1,3-butanediol } & 0.84 & 0.80 & 0.83 \\ \text { Authentic } \beta \text {-hydroxybutyric acid } & 0.84 & 0.75 & 0.86\end{array}$


No spot was detected on paper chromatogram but the product was probably volatile. With glycerol and glucose, a spot giving an $R f$ value of 0.32 was obtained with solvent $A$. With methanol, ethanol, DL-1,2,4-butanetriol and pentaerythritol, the $\mathrm{pH}$ of the reaction mixture did not change and no spots were detected.

\section{Oxidation product of 1,2-ethanediol}

No acidic or carbonic compounds were detected in the culture grown for three days with $2 \%$ ethanol as the sole source of carbon. Thus, this broth was used for experiments on oxidation. The broth was adjusted to $\mathrm{pH} 7$ with $0.1 \mathrm{~N} \mathrm{NaOH}$, and $2 \mathrm{~g}$ of 1,2-ethanediol and $2 \mathrm{~g}$ of calcium carbonate were added aseptically to $100 \mathrm{ml}$ of the medium. The mixture was incubated for three days. The cells and the residual calcium carbonate were removed by centrifugation and the supernatant was adjusted to $\mathrm{pH} 1.5$ with $\mathrm{H}_{2} \mathrm{SO}_{4}$ and extracted with ether. The residual solution was titrated with $0.1 \mathrm{~N} \mathrm{NaOH}$ and the amount of acidic compound was estimated as $1.3 \mathrm{~g}$ of glycolic acid. Na glycollate was purified by crystallizing twice from water and ethanol. The free acid was prepared by column chromatography on Dowex $50\left(\mathrm{H}^{+}\right)$ and concentrated in vacuo until crystals started to form. Crystallization was continued in a cold room. The material had a melting point of $73 \sim 74^{\circ} \mathrm{C}$ (reported value ${ }^{1 /}$ for glycolic acid, $73 \sim 75^{\circ} \mathrm{C}$ ) and this was not depressed when the material was mixed with an authentic sample of glycolic acid. The melting point of its $p$-bromophenacyl ester was $137 \sim 138^{\circ} \mathrm{C}$ (reported value, ${ }^{1 /} 137 \sim 138^{\circ} \mathrm{C}$ ). The infrared spectrum of the product from 1,2-ethanediol coincided with that of the glycolic acid. From these results the product was confirmed to be glycolic acid.

\section{Oxidation product of DL-1,3-butanediol}

The same procedure as that described above was followed, starting with a mixture $(100 \mathrm{ml})$ of $2 \%$ DL-1,3-butanediol, $2 \%$ calcium carbonate and the broth described above. The cells were removed from the mixture by centrifugation. The supernatant was acidified to $\mathrm{pH} 1.5$ by addition of $\mathrm{H}_{2} \mathrm{SO}_{4}$ and extracted continuously for $24 \mathrm{hr}$ with ether. The ether phase was removed by distillation. The residual pale yellow oil was dissolved in water and neutralized with $1 \mathrm{~N} \mathrm{NaOH}$ and the amount of acidic compound formed was estimated to be $0.5 \mathrm{~g}$ as $\beta$-hydroxybutyric acid. After distillation in vacuo, the crystalline $\mathrm{Na}$ salt was dissolved in a minimal amount of absolute ethanol and slowly poured with stirring into $50 \mathrm{ml}$ of acetone. The resulting crystals were filtered off and washed several times with ether. The material had a melting point of $164 \sim 165^{\circ} \mathrm{C}$ (reported value ${ }^{1 \text { ) for }}$ $\beta$-hydroxybutyric acid, $163 \sim 164^{\circ} \mathrm{C}$ ) and this was not depressed when the material was mixed with an authentic sample of $\beta$-hydroxybutyric acid. The melting point of its $p$ phenyl-phenacyl ester was $105 \sim 106^{\circ} \mathrm{C}$ (reported value ${ }^{1 i}$ for the ester of $\beta$-hydroxybutyric acid, $105 \sim 105.5^{\circ} \mathrm{C}$ ).

\section{Product from glycerol and glucose}

The products from glycerol and glucose were examined by the same procedure as that described above, except that calcium carbonate was omitted. Incubation mixture (100 $\mathrm{ml}$ ), containing $2 \mathrm{~g}$ of glycerol or glucose was shaken. No acidic substance was detected by paper chromatography. The cells were removed from the reaction mixture by centrifugation and then the supernatant was deionized with Dowex 2 and Dowex 50. The deionized solution was concentrated to a syrup. This was dissolved into $0.5 \mathrm{ml}$ water and placed on a cellulose column, and fractionated using the developing solvent: $n$-butanol:acetic acid : water $=4: 1: 5, \mathrm{v} / \mathrm{v})$. The appropriate fractions were collected in a fraction collector, and evaporated to dryness. The residue was crystallized from ethanol and water. It had a melting point of $101 \sim 102^{\circ} \mathrm{C}$ (reported value

\footnotetext{
7) "Handbook of biochemistry and biophysics", p. 138, by Ed. H. C. Damm, P. K. Besch and A.J. Goldwyn, The World Publishing Co., Cleveland and New York, 1967.
} 
for D-arabinitol, $103^{\circ} \mathrm{C}$ ). The results of elementary analysis were as follows; Found; C, 39.24; $\mathrm{H}, 8.24$. Calculated for $\mathrm{C}_{5} \mathrm{H}_{22} \mathrm{O}_{5}: \mathrm{C}$, $39.47 ; \mathrm{H}, 7.89 \%$. The infrared spectrum of this compound corresponded to that of $\mathrm{D}$ arabinitol. $[\alpha]_{D}^{30}=+8.2(c, 5.0$ in borax saturated solution) (reported value ${ }^{8 /}$ for $\mathrm{D}$-arabinitol, $[\alpha]_{D}=+8.28(c, 9.78)$. These results show that the compounds formed from glycerol and glucose were $\mathrm{D}$-arabinitol. The yields were $320 \mathrm{mg}$ and $60 \mathrm{mg}$ from $2 \mathrm{~g}$ of glycerol and glucose, respectively.

\section{DISCUSSION}

It has previously been shown that a cell suspension of bakers' yeast accumulates a significant amount of acetol under aerobic conditions when 1,2-propanediol is added as substrate $^{9 /}$ and some strains of the genus Candida can utilize 1,2-propanediol as a sole source of carbon. ${ }^{101}$ Moreover, alcohol dehydrogenase from bakers' yeast has been shown to react with 1,2-ethanediol. ${ }^{11}$ However, the oxidations of various glycol compounds by yeast have not been extensively studied. Using strains of the genus Acetobacter, extensive studies on the oxidation of glycols have been done by Kersters et al. ${ }^{11}$ and resting cells of 14 different strains of acetic acid bacteria were found to oxidize 1,2-ethanediol, DL-1,2-propanediol, 1,3-propanediol, DL-1,3-butanediol, meso-2,3-butanediol and 1,4-butanediol. These workers isolated the following end products of oxidation from a variety of glycols: glycolic acid from 1,2-ethanediol, $\beta$-hydroxypropionic acid from 1,3-propanediol, succinic acid from 1,4-butanediol, glutaric acid from 1,5-pentanediol, adipic acid from 1,6-hexanediol, pimelic acid from

8) H. Onishi, Bull. Agr. Chem. Soc. Japan, 24, 131 (1960).

9) C. G. Huggins and O. N. Miller, J. Biol. Chem., 221, 719 (1956).

10) M. Ishii, T. Harada and Z. Nikuni, Nippon Nogeikagaku Kaishi, 33, 889 (1959).

11) "Methods in Enzymology" Vol. 1, ed. by S.P. Colowick and N. O. Kaplan, Academic Press Inc., New York, 1955 p. 500. 1,7-heptanediol and DL- $\beta$-hydroxybutyric acid from DL-1,3-butanediol.

Our present experiments with Hansenula miso IFO 0146 showed that resting cells oxidized 1,2-ethanediol, DL-1,2-propanediol, 1,3-propanediol, meso-2,3-butanediol, DL-1,3-butanediol and 1,4-butanediol. The oxidation products from 1,2-ethanediol and DL-1,3-butanediol were isolated and identified chemically as glycolic acid and $\beta$-hydroxybutyric acid. This organism can oxidize these glycols although it cannot utilize them as sole sources of carbon. Acetobacter aceti ${ }^{11}$ which cannot grow on a liquid medium with DL-1,3-butanediol as a sole source of carbon, is known to form $\beta$ hydroxybutyric acid from DL-1,3-butanediol. Thus, some organisms such as Hansenula miso and Acetobacter aceti $i^{11}$ can oxidize some glycols. These biological reactions seemed to be of practical importance both in industry and in preparative organic chemistry since various glycols can be easily made chemically from petroleum.

Pseudomonas methanica can utilize methane as the sole source of carbon but not ethane or propane. However, this organism can oxidize ethane and propane if these compounds are present in the culture medium with methane. ${ }^{121}$ Similar phenomena were observed in experiments using aromatic compounds with a $n$ alkane side chain in the presence of $n$ alkane. ${ }^{13}$ This phenomenon is called cooxidation. In our experiments, when various glycol compounds were present in culture media with ethanol, oxidation products were formed from them (unpublished data). To obtain these oxidation products in good yield, it is still uncertain which method is better, cooxidation or oxidation with resting cells grown on ethanol medium.

With Hansenula miso, $\beta$-hydroxypropionic acid and $\gamma$-hydroxybutyric acid were formed

12) E. R. Leadbetter and J. W. Foster, Arch. Microbiol., 9, 383 (1961).

13) J. B. Davis and R. L. Raymond, Appl. Micro biol., 9, 383 (1961). 
from 1,3-propanediol and 1,4-butanediol respectively, and these were identified by paper chromatography, while the Gluconobacter oxydans $^{11}$ succinic acid was formed from 1,4butanediol although $\beta$-hydroxypropionic acid could be formed from 1,3-propanediol as in the case with Hansenula miso. Hansenula miso produced erythritol and glycerol when grown in media containing glucose as the sole source of carbon and these were identified by paper chromatography, while the resting cells formed D-arabinitol from glucose as well as glycerol. Spencer et $a l^{141}$ demonstrated that many osmophilic yeasts could produce $\mathrm{D}$-arabinitol as well as glycerol, erythritol and mannitol in good yields under conditions. Hansenula miso did not produce any polyhydric alcohol from ethanol.

14) J.F. T. Spencer and H. R. Sallans, Can. J, Microbiol., 2, 72 (1956).
Hansenula miso produced quite large amounts of cell when grown with ethanol rather than with glucose or glycerol. Recently, utilization of ethanol as a carbon source for fermentation have been reported. ${ }^{15,16}$ ) Production of protein from ethanol by microorganisms has industrial possibilities because ethanol is easily prepared chemically from petroleum. Our study is of great importance since the yield of cell from ethanol by the organism is extremely high and also the composition of media used is very simple.

Acknowledgements. The authors wish to thank Dr. T. Hasegawa, Institute for Fermentation, Osaka for kindly supplying type culture.

15) T. Harada, Y. Murooka and Y. Izumi, Biochem. Biophys. Res. Commun., 28, 485 (1967).

16) T. Oki, Y. Sayama, Y. Nishimura and A. Ozaki, Agr. Biol. Chem., 32, 119 (1968). 